tastefully decorated in a simple manner with fragments of veneer of different colours. They are accompanied by models which still better illustrate the means adopted in mountainous countries, and must prove exceedingly instructive to students of forestry.

Next in order come the tools used in the various operations of cutting, transporting, and working the timber and peeling the bark. Some of the axes and saws are of extremely peculiar shape, but admirably fitted for the purposes for which they are intended.

According to a piinted table hung on the end wall, the area of the Japanese Empire is $38,563,718$ chos (a cho $=$ 2.450 acres), the area of forest (excluding the islands of Okinawa and Hokkaido) being i $, 866,626$ chos, or rather less than one-third of the country. Of this area 5,259,182 chos are worked by the Government, and 6,607,443 chos by private individuals. About a quarter of the Empire has, however, not yet been surveyed; the above figures, therefore, only refer to the surveyed portion. Accompanying this table is a map giving the distribution of trees in Japan, and marking out certain zones, each indicated by some particular tree forming a prominent feature in the landscape. Of these zones Ficus Wightiana characterises the lowest, Pinus Thunbergii the second; then follow in order Fagus sylvatica, Abies Veitchii, and Pinus Cembra. The extent of these zones is marked in colours on the map, and on excellent coloured drawings representing the habit of the five trees, and their foliage, flowers, and fruit in life-size are presented at one glance. The less important productions of the forests are appropriately illustrated by smaller collections, a simple expedient by which an idea of their relative consequence is easily conveyed. Fungi, dried and preserved in pickle, and a dried lichen (a species of Gyrophora), and a collection of seeds of forest-trees, well preserved, and carefully named, are placed near. Several fungi are cultivated on special trees. According to notes affixed to the trec-sections, among the trees thus employed are Celtis sinensis, Carpinus laxiflora, Quercus crispula, cuspidata, and glandulifera.

Roots, barks, and seeds used in medicine are not so well represented as usual. Liven menthol, now tolerably well known in this country as a remedy for neuralgia, is not exhibited. A beautiful specimen of insect wax resembling spermaceti in appearance, but much harder, and identical with that used in China to coat candles to prevent their guttering, is exhibited. The insect producing it is cultivated on Ligustrum Ibotu and Fraxinus pubinervis.

An exceedingly ingenious double chop-stick is here shown, consisting of a piece of white wood, slit two-thirds of its length; on pulling the pieces apart, a wooden toothpick is scen inclosed in the centre. As the wood has never been entirely split, it is puzzling to know how the toothpick was inserted. This is done by cutting it with a special instrument when the wood is wet and can be extencled. The leaves of two other plants besides those of tobacco are shown, the one made into cigarettes, and the other simply dried for smoking (Sterculia platanifolia).

The cooperage work seems to be carefully done, the barrels having polished surfaces, and in some instances the bands are made of plaited bamboo. The polishing of rough surfaces appears to be effected by the rough leaves of Aphananthe aspera and the stems of a species of Equisetum. Japanese tooth-brushes are exhibited, made of the frayed out ends of a piece of white wood; and combs, and even tooth-combs, are made of similar material of a harder character, such as the wood of Olea Aquifolium and Hovenia dulcis. Dyeing and tanning barks are comparatively few in number, and walking sticks do not present any great variety, only a few being engraved or ornamented. A simple flower-pot for the wall of drawing-rooms consists of two joints of a large bamboo, with a piece cut out at the side of each joint so as to permit of a fern or bouquet depending over it.
In the left-hand court may be seen some bent wood furniture that might fairly compete with that of Austrian manufacture. In one corner may be seen a series of young trees four or five years old, imported from France, Germany, the United States, and other countries; indicating that acclimatisation of the useful trees of other countries has already been commenced in Japan. Woodengraving and printing in one or more colours is illustrated by the engravings placed side by side with the blocks. The celebrated Japanese lacquer is exhibited in the crude state, and also applied to knick-knacks and other articles, some specimens of lacquered slabs having so high a polish as to appear like glazed ornamental tiles. These are accompanied by a coloured drawing of the foliage and flowers of the lacquer-tree painted on the wood of the same tree and framed, with other portions having the bark attached. Several other useful timber-trees are illustrated in the same ingenious manner. The almost transparent yet strong and tough paper made from the fibre of the paper mulberry-tree (Broussonettia papyrifera) is shown, but its manufacture is not illustrated by drawings, the exhibits being limited to products. This paper rolled into the form of a spill is strong enough to be used like string. Exceedingly thin planed shavings of wood, scarcely thicker than the paper above alluded to, occupy a conspicuous position. These are used for packing butter or other goods of similar description. A cursory glance at the notes appended to the sections of wood reveals many interesting facts regarding some Japanese trees and shrubs commonly cultivated in this country. Thus an oil is obtained from the seeds of the common Camellia ( $C$. japonica), and rope is made from the stems of Wistaria sinensis. Charcoal, for the manufacture of gunpowder, is prepared from the wood of Paulownia imperialis, and the wood of the deliciously-scented Olea fragrans is used for wood-engraving and combs. A shrub, also indigenous in this country, Viburnum opulus, furnishes tooth-picks. A very ingenious use of the trunks of trees is the hollowing them out into drain-pipes, each about 6 or 8 feet long, and fitting into each other at the end. On the walls of this court illustrations are given of the mode of preventing the slipping away of soil on mountain-sides, and of the trees and shrubs and herbs useful for binding sandy soil or embankments, \&c. Altogether the Japanese section is an exceedingly interesting one, and offers many useful suggestions to the foresters of Western countries.

\section{PRACTICAL TAXIDERMY}

$\triangle$ MIDST the many criticisms which are passed by visitors upon the collections in the new Natural History Museum of South Kensington, there is always to be found a word of praise for the improved appearance of the mounted animals in that Museum, and it may fairly be said that the encomiums which are heard on all sides have been justly earned by Dr. Günther and the staff of the Zoological Department; that is to say, if an honest endeavour to present to the public something better than can be seen in other museums counts for anything. The officers of the British Museum, in transferring the zoological collections from Bloomsbury to South Kensington, were heavily handicapped, for it was impossible to commence the mounting of the collections de novo, and they therefore had upon their hands a vast number of interesting specimens unfit to exhibit to the public, but valuable to the naturalist, and worthy of preservation as forming a historical part of that great zoolngical collection which is admitted by naturalists to be intrinsically the finest in the world. For some time before the removal a careful selection of duplicate specimens had been made, and these had been distributed to various provincial museums, but all those which possessed any scientific value, such as types, \&c., have been carefully unmounted and added to the collection of skins, and it was curious 
to note the progress of the art of taxidermy which these specimens exhibited. It is notorious that for many years the authorities of the Zoological Department have been troubled with the preservation of antique specimens of natural history which seemed to be falling into a state of natural decay, although no actual reason could be assigned for their dissolution, and moths and beetles have never been known to do any harm to the collections, thanks to the constant care which is exercised in that department. But on dismounting some of the ancient specimens, such as those presented by Colonel Montagu, it was discovered that they had never been properly skinned, and with the exception of the extraction of the entrails, the bones and flesh of the birds had been left entire, and apparently without an attempt to further preserve the specimens. The result may be imagined, and the difficulty of preserving these interesting relics will be fully appreciated by the naturalist of to-day. It has often been a source of wonder to zoologists as to what has become of many of the types of species recorded by Latham and the older writers on ornithology as existing in the British Museum, which certainly are no longer in the national collection. The records of the Museum show that they never descended to modern times, and there can be little doubt that the defective preparation of a hundred years ago was inadequate for their preservation, and that they were allowed to fall into decay by the earlier custodians of the national Museum, in whom the sacred value of a type was not so inherent as it is in the age in which we live.

We may hope that the improved preparation of the specimens in the Natural History Museum marks the commencement of a new era in the art of taxidermy, for the skilful mounting of animals is a real art, and ought to be recognised as such. An artist who portrays animal life successfully reaps the full appreciation of his countrymen, and is well paid for his work, but hitherto the taxidermist has never been properly appreciated, and until adequate remuneration is provided for the artists who reproduce natural specimens, we can never hope for the success of taxidermy as an art which ought to rank as high as that of the animal painter. The undoubted success which has attended the production of the groups of British birds which now adorn the corridors in the Natural History Museum is a great encouragement to those who have at heart the welfare of the art of taxidermy, and it cannot be denied that the mounting of these groups does credit to all concerned. We are aware that Prof. Flower (himself no mean taxidermist) takes a great interest in the improvement in the mounting of animals in the Museum of which he is so able a Director, and the exertions of Dr. Günther in this direction have been manifest since his appointment as Keeper of the Zoological Department in the British .Museum, while the frequent occurrence of Lord Walsingham's name as a donor of many of these beautiful groups of "British birds in their haunts," shows the practical utility of having as a trustee a naturalist who labours to supply the wants of the institution of which he is one of the guardians. In the Bird Gallery itself, as well as in that of Mammalia and Osteology, the same wish to improve the natural appearance of the specimens exhibited is seen at every turn, and it is to be hoped that the lesson thus taught by the British Museum will be imprinted on the mind of cvery provincial curator, who will feel henceforth that the value of the collection under his charge will consist not so much in the array of mounted specimens which he can muster on his shelves, as in the excellent preparation of the few leading types which are really all that are necessary for the instruction of the public.

The above thoughts have been inspired by a perusal of a little work which has fallen into our hands, viz. the second edition of Mr. Montagu Brown's Essay on Taxidermy. Mr. Brown is the Curator of the Leicester
Museum, and he is a man of whom any provincial museum may well be proud. In a lectuxe delivered many years ago at Leicester Mr. Bowdler Sharpe gave some hints on what he conceived it to be the object of a County museum. It seemed to him that in the first place it was expected of every County museum to make as perfect a collection as possible of the natural productions of that County-that this should be the aim and object of every curator, and that all these exhibits should be arranged in the most popular and attractive form. It was impossible, he pointed out, for a local museum to attempt to show a perfect collection of all the classes of animals. This ought to be left to the British Museum; but he insisted that it was within the province of every such museum to exhibit a typical series of animals which would be useful for comparison with local species, and would educate the minds of an intelligent public towards an appreciation of the varied forms of animal life upon the globe, as compared with the zoology and botany of the county in which they lived. Shortly after the Committee of the Leicester Museum carried out this idea to a limited extent under the curatorship of Mr. Harrison, a most intelligent custodian, who is, we believe, now located at Birmingham; but the plan was fully developed by his successor, Mr. Brown, who has employed his talents as a taxidermist in a popular direction, and the result is that the collection of birds at Leicester is mounted in cases with the natural surroundings explaining their habits at a glance, and in a manner with which no guide-book attempting to illustrate a collection on a conventional plan can hope to vie. It may be a question for naturalists whether this will not be the museum of the future, but as evidence of the value of practical taxidermy this may be considered already un fait accompli; and in making these remarks it would be unfair not to mention the names of some of those who in England have contributed to the improvement of this art. Of these the honoured name of John Hancock stands first, for the influence of Waterton, who strove to import into this country an improved system of mounting animals, seems to have been but small among the generation which followed him. Mr. Hancock's groups in the Great Exhibition of $185 \mathrm{I}$ left an indelible impress upon British taxidermy, and his rendering of a bird of prey is only equalled for life-like delineation by one of Wolf's pictures. Mr. A. D. Bartlett, the wellknown Superintendent of the Zoological Gardens, is certainly one of the best taxidermists which this country has produced, while the art of motnting Mammalia has been studied with success by Mr. Rowland Ward and Mr. Edward Gerrard - most of the best examples of the latter class in the British Museum having been mounted by the last-named artist. Many provincial men, such as Mr. Swaysland of Brighton, Mr. Shaw of Shrewsbury, and Mr. Quartermain of Stratford-on-Avon, have proved their ability as taxidermists, and London itself possesses adepts in the art who are equal to the great taxidermist Termayer of $\mathrm{Hol}$ land, whose masterpieces may be seen in the Museums of Amsterdam and Leyden ; but we doubt whether anybody has exercised more influence on the improvement in the mounting of animals than Mr. E. 'T. Booth of Brighton, whose collection of British birds exhibited in the Dyke Road Museum is one of the sights of England. To him belongs the credit of being the first to attempt a collection of British birds with their natural surroundings, and it is upon the lines introduced by Mr. Booth that the beautiful groups of our native species in their natural habitats has been attempted at the British Museum; and if the genius of Mr. Pickhardt who has mounted the birds, and of Mr. Mintorn, to whose skill the beautiful modelling of the flowers and trees is due, does not satisfy the aspirations of British naturalists, we shall feel that the improvements in the taxidermy of recent years have no real existence. 